\title{
ANALYSIS OF TIMES AND EFFICIENCIES OF THE MECHANIZED HARVEST OF SUGARCANE (Saccharum spp.)
}

\author{
SANTOS, Neisvaldo Barbosa dos ${ }^{1}$ \\ TEIXEIRA, Mauri Martins ${ }^{2}$ \\ FERNANDES, Haroldo Carlos ${ }^{2}$ \\ GADANHA JÚNIOR, Casimiro Dias ${ }^{3}$
}

ISSUE DOI: $10.3738 / 1982.2278 .2794$

SUMMARY: Sugarcane culture directed to sugar mills is of great economic and social importance in Brazil. Harvesters are the most important equipment in the sugarcane mechanized harvesting system, since the production process in sugar mills depends on machine operating performance, which is directly related to field efficiency. Therefore, efficiency is relevant because it involves the service time and operational efficiency of the harvester and it takes place when the operation is implemented. The current study aims to analyze the times and efficiencys in sugarcane mechanized harvesting. To current study took under consideration primary data on the mechanized harvesting of a sugarcane plant, which were analyzed using descriptive statistics. The reduction in time lost increases the time worked. Operational and use efficiency have strong impact on the mechanized harvesting performance.

Keywords: Agricultural engineering, agricultural mechanization, agronomy, management.

\section{ANÁLISE DE TEMPOS E EFICIÊNCIAS DA COLHEITA MECANIZADA DE CANA- DE-AÇÚCAR (Saccharum spp.)}

\begin{abstract}
RESUMO: No Brasil a cultura da cana-de-açúcar direcionada às usinas, representa grande importância econômica e social. No sistema de colheita mecanizada dessa matéria-prima, a colhedora é o equipamento mais importante, pois para uma usina, o processo de produção depende do desempenho operacional da máquina, que está diretamente relacionado à eficiência de campo. Portanto, a eficiência é relevante porque envolve os tempos de serviço e eficiências operacionais da colhedora, que ocorrem na execução da operação. Neste trabalho objetivou-se analisar tempos e eficiências da colheita mecanizada de cana-de-açúcar. Para o trabalho foram considerados dados primários da colheita mecanizada de cana-de-açúcar de uma usina, analisados através da estatística descritiva. A diminuição dos tempos perdidos eleva os tempos trabalhados. A eficiência operacional e de utilização apresenta forte impacto para o desempenho da colheita mecanizada.
\end{abstract}

Palavras-chave: Agronomia, engenharia agrícola, gerenciamento, mecanização agrícola.

\section{INTRODUCTION}

Sugarcane cultivation directed to sugar-and-ethanol-processing plants in Brazil estimates total area and production of 8.84 million hectares and 647.60 million tons, respectively, for the 2017/2018 crop, (CONAB, 2017).

The production process is very important to processing plants. It is necessary to keep the constant flow and quality of mechanically harvested sugarcane in order to meet the demand for by-products

\footnotetext{
${ }^{1}$ Universidade Federal do Piauí-UFPI. Doutorando em Engenharia Agrícola pela Universidade Federal do Ceará.UFC

${ }^{2}$ Universidade Federal de Viçosa-UFV

${ }^{3}$ Escola Superior de Agricultura Luiz de Queiroz-ESALQ/USP
} 
production, since the production process depends on the operational performance of the mechanical harvesting system (SANTOS et al., 2014b).

According to Abdel Mawla et al. (2014), Cervi et al. (2015), Ramos (2013), Viator et al. (2007) and Yadav et al. (2002), the sugarcane harvester operating performance is directly related to field efficiency FE. According to Santos et al. (2014a), field efficiency expresses the managerial conditions to operate in the plant's plot, taking under consideration the operating times among different implementation means.

Operating times represent the machine FE, which according to Banchi et al. (2008), Linhares et al. (2012), Ma et al. (2015), Silveira et al. (2006), Simões et al. (2011) and Yousif et al. (2013) results from the ratio between the effectively used time and the total time allotted to operate the equipment. According to Balastreire (1990), machine service time refers to total field time, which comprises the effective time per area, the non-proportional time lost to the area and the proportional time lost to the area.

Mialhe (1974) defines operating times as preparation, interruption and production times. Preparation time refers to the harvester preparation for operating and storing. Interruption time results from the machine work in operation, such as headboard maneuvers, unclogging, adjustments and refueling. The production time exclusively concerns the productive work in which the harvester active parts effectively perform the agricultural operation.

Managing the harvester is essential to the sugarcane mechanized harvesting. Banchi \& Lopez (2007) state that the planning of mechanized farming operations must be done in order to reduce the amount of hours the equipment is not in use. Hansen et al. (2002) conducted a study on delays that take place during the sugarcane harvesting operational times and last until plant milling. They concluded that the total delay time over a week was approximately 10:30 hours.

According to Santos et al. (2015), regarding the sugarcane mechanized harvesting operation, among the harvester service times such as productive, accessory, auxiliary and incapacity times as well as time lost and time worked, the accessory time (interruption) has major influence on the machine service time due to the high number of headland maneuvers needed to perform the work.

Due to the relevance of headland maneuvers, Hansen et al. (2007) conducted a study aiming to determine a maneuvering standard path by using different sizes of maize harvesting platforms in order to achieve the lowest total waiting time to perform the maneuvers. The authors concluded that larger platform demanded less maneuvering time. Therefore, the current study aims to analyze the times and efficiencys in sugarcane mechanized harvesting.

\section{MATERIAL AND METHOD}

This work is a case study carried out during a journey working daily of the mechanized harvesting of sugarcane in a plant. To study took under consideration primary (raw) data of the mechanized harvesting, which were analyzed using descriptive statistics. The primary data are worked hours of the sugarcane harvester, during the journey working daily, that meets the methodology proposed by (GONÇALVES et al., 1993).

During the operation, the machine engine was kept at 2,200 rpm, work speed of $1.60 \mathrm{~m} \mathrm{~s}^{-1}$ and estimated consumption of $34.00 \mathrm{~L} \mathrm{~h}^{-1}$. The harvested area had 3.50 ha, with average sugarcane productivity of $68.50 \mathrm{t} \mathrm{ha}^{-1}$ and harvested sugarcane production of approximately $240.00 \mathrm{t}$.

The current study's results were generated by means of an Excel ${ }^{\circledR}$ spreadsheet. The considered methodology meets the study's goal and is in line with the research proposals by (GONÇALVES et al., 1993) and (BANCHI et al., 2012). 
The harvester service times were defined according to Gonçalves et al. (1993), as follows: productive time (PRT), accessory time (ACT), auxiliary time (AXT), incapacity time (INT), time lost (TLO) and time worked (TWR).

The productive time (PRT) results from the time the harvester was actually working on the harvested plot.

The accessory time (ACT) is defined by the time of headland maneuvers (HMT) performed by the machine in the edge of the plot.

The auxiliary time (AXT) is calculated by the sum of the preventive maintenance times (PMT) and final adjustments (FA) of the harvester, equation (1).

$$
\mathrm{AXT}=\mathrm{PMT}+\mathrm{FA}
$$

Wherein:

AXT: is the auxiliary time (h);

PMT: is the preventive maintenance time (h);

FA: is the final adjustments (h).

The incapacity time (INT) is defined by the existence of climate inadequacies along the daily working hours.

The time lost (TLO) is calculated by the sum of the harvester-clogging time (HCT) and time waiting for plot transshipment (TWPT), equation (2).

$$
\mathrm{TLO}=\mathrm{HCT}+\mathrm{TWPT}
$$

Wherein:

TLO: is the time lost (h);

HCT: is the harvester-clogging time (h);

TWPT: is the time waiting for plot transshipment (h).

The time worked (TWR) is defined by the sum of productive time (PRT) and accessory time (ACT), equation (3).

$$
\mathrm{TWR}=\mathrm{PRT}+\mathrm{ACT}
$$

Wherein:

TWR: is the time worked (h);

PRT: is the productive time (h);

ACT: is the accessory time (h).

The machine's operational efficiencies were determined according to Banchi et al. (2012) as operational efficiency (OPEF), aptitude efficiency (APEF), utilization efficiency (UTEF), availability efficiency (AVEF), take efficiency (TKEF) and global efficiency (GLEF).

The operational efficiency (OPEF) is calculated by the ratio between worked hours (WRH) and auxiliary hours (AXH), equation (4).

$$
\mathrm{OPEF}=\frac{\mathrm{WRH}}{\mathrm{WRH}+\mathrm{AXH}}
$$


Wherein:

OPEF: is the operational efficiency (\%);

WRH: is the worked hours (h);

AXH: is the auxiliary hours (h).

The aptitude efficiency (APEF) is defined by the ratio among worked hours (WRH), auxiliary hours (AXH) and incapacity hours (INH), equation (5).

Wherein:

$$
\mathrm{APEF}=\frac{\mathrm{WRH}+\mathrm{AXH}}{\mathrm{WRH}+\mathrm{AXH}+\mathrm{INH}}
$$

APEF: is the aptitude efficiency (\%);

INH: is the incapacity hours (h).

The utilization efficiency (UTEF) is calculated by the ratio among worked hours (WRH), auxiliary hours (AXH), incapacity hours (INH) and lost hours (LOH), equation (6).

Wherein:

$$
\mathrm{UTEF}=\frac{\mathrm{WRH}+\mathrm{AXH}+\mathrm{INH}}{\mathrm{WRH}+\mathrm{AXH}+\mathrm{INH}+\mathrm{LOH}}
$$

UTEF: is the utilization efficiency (\%);

LOH: is the lost hours (h).

The availability efficiency (AVEF) is defined by the ratio among worked hours (WRH), auxiliary hours (AXH), incapacity hours (INH), lost hours ( $\mathrm{LOH})$ and maintenance hours (MNH), equation (7).

$$
\mathrm{AVEF}=\frac{\mathrm{WRH}+\mathrm{AXH}+\mathrm{INH}+\mathrm{LOH}}{\mathrm{WRH}+\mathrm{AXH}+\mathrm{INH}+\mathrm{LOH}+\mathrm{MNH}}
$$

Wherein:

AVEF: is the availability efficiency (\%);

$\mathrm{MNH}$ : is the maintenance hours (h).

The take efficiency (TKEF) is calculated by the ratio among worked hours (WRH), auxiliary hours (AXH), incapacity hours (INH), lost hours ( $\mathrm{LOH})$, maintenance hours (MNH) and the total hours in a day, equation (8).

$$
\mathrm{TKEF}=\frac{\mathrm{WRH}+\mathrm{AXH}+\mathrm{INH}+\mathrm{LOH}+\mathrm{MNH}}{24}
$$

Wherein:

TKEF: is the take efficiency (\%).

The global efficiency (GLEF) is defined by the ratio between worked hours (WRH) and the total hours in a day, equation (9).

$$
\mathrm{GLEF}=\frac{\mathrm{WRH}}{24}
$$

Wherein:

GLEF: is the global efficiency (\%).

A proposal was elaborated in order to determine the field efficiency (FE), and the ratio between the operational efficiency (OPEF), the aptitude efficiency (APEF), the utilization efficiency (UTEF), the 
availability efficiency (AVEF), the take efficiency (TKEF), the global efficiency (GLEF) and the total number of efficiencies, equation (10).

$$
\mathrm{FE}=\frac{\mathrm{OPEF}+\mathrm{APEF}+\mathrm{UTEF}+\mathrm{AVEF}+\mathrm{TKEF}+\mathrm{GLEF}}{6}
$$

Wherein:

FE: is the field efficiency (\%).

A proposal was developed to define the field inefficiency (FI), and the difference between the maximum efficiency limit and the field efficiency (FE), equation (11).

$$
\mathrm{FI}=100-\mathrm{FE}
$$

Wherein:

FI: is the field inefficiency $(\%)$.

\section{RESULTS AND DISCUSSION}

The data on the sampled times showed minimum value of 0.31 , maximum value of 0.62 , mean $(\overline{\mathrm{X}})$ of 0.48 , kurtosis of -1.53 , standard deviation (s) of 0.09 and variation coefficient (VC) of $18.25 \%$. Table 1 shows the sugarcane harvester service times. Service times include productive time (PRT), accessory time (ACT), auxiliary time (AXT), time incapacity (INT), time lost (TLO) and time worked (TWR).

Table 1. Harvester service times.

\begin{tabular}{lccc}
\hline & \multirow{2}{*}{ ACRONYM } & \multicolumn{2}{c}{ TIMES } \\
\cline { 3 - 4 } & & (h:min:s) & (h) \\
\hline Productive Time & PRT & $04: 10: 32$ & 4.18 \\
Accessory Time & ACT & $00: 36: 54$ & 0.62 \\
Auxiliary Time & AXT & $00: 39: 21$ & 0.66 \\
Incapacity Time & INT & $00: 00: 00$ & 0.00 \\
Time Lost & TLO & $02: 04: 18$ & 2.07 \\
Time Worked & TWR & $04: 47: 26$ & 4.79 \\
\hline
\end{tabular}

TWR was the most representative $(4.79 \mathrm{~h})$ throughout the harvester's daily working hours, since it results from PRT and ACT. PRT refers to the time when the harvester was effectively processing the raw materials harvested along the plot, which corresponded to $4.18 \mathrm{~h}$. ACT results from the performed headland maneuvers, which are necessary for the operation to be performed, and it was approximately $0.62 \mathrm{~h}$. AXT results from the maintenance and final adjustments given to the harvester, which required $0.66 \mathrm{~h}$

Throughout the operation, the harvester was not incapacitated, since the agro-climatic conditions were favorable. The machine kept its capabilities or abilities, thus INT was $0.00 \mathrm{~h}$. TLO was $2.07 \mathrm{~h}$, due to the unexpected harvester downtimes during operation - "clogging" and the time waited for internal load (transshipment) in the plot. In general, TLO and AXT may vary because they directly depend on the agricultural (field) and mechanical (repairshop) management method adopted by the plant, respectively.

Figure 1 shows the service times' distribution percentage of sugarcane harvesters. It is comprised of PRT, ACT, AXT, INT and TLO. 
Figure 1. Service times distribution of harvester.
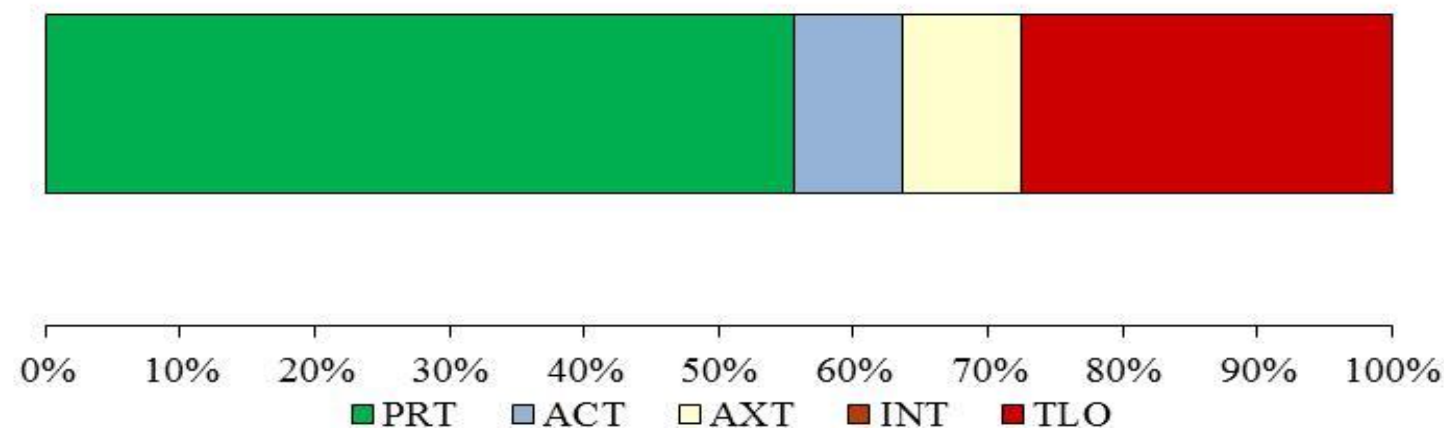

As for the mechanized harvesting operation, the harvester mostly processes raw material which resulted in 55.54\% PRT. The headland maneuvers of the harvester, which are necessary in the operation, resulted in 8.18\% ACT. However, factors such as crop spacing, geometric shape of the plot and others should be taken under consideration, since they may positively or negatively influence the operation. AXT generally represents $8.72 \%$ of the machine daily working hours. Since the harvester was able to operate, INT was $0.00 \%$, because ACT and AXT were used. As for the operation conditions, TLO was 27.56\%. TLO happens due to unexpected downtimes and it should be avoided to the maximum, since it decreases machine TWR.

As for the mechanized harvesting operation in the processing plant, it is worth achieving the highest TWR in order to meet harvested raw materials' quantity and quality demands for by-product production and to increase the competitiveness of the plant in relation to other.

Figure 2 shows the distribution of the sugarcane harvester efficiencies. The distribution comprises operational efficiency (OPEF), aptitude efficiency (APEF), utilization efficiency (UTEF), availability efficiency (AVEF), take efficiency (TKEF), global efficiency (GLEF), field efficiency (FE), and field inefficiency (FI).

Figure 2. Harvester efficiencies distribution.

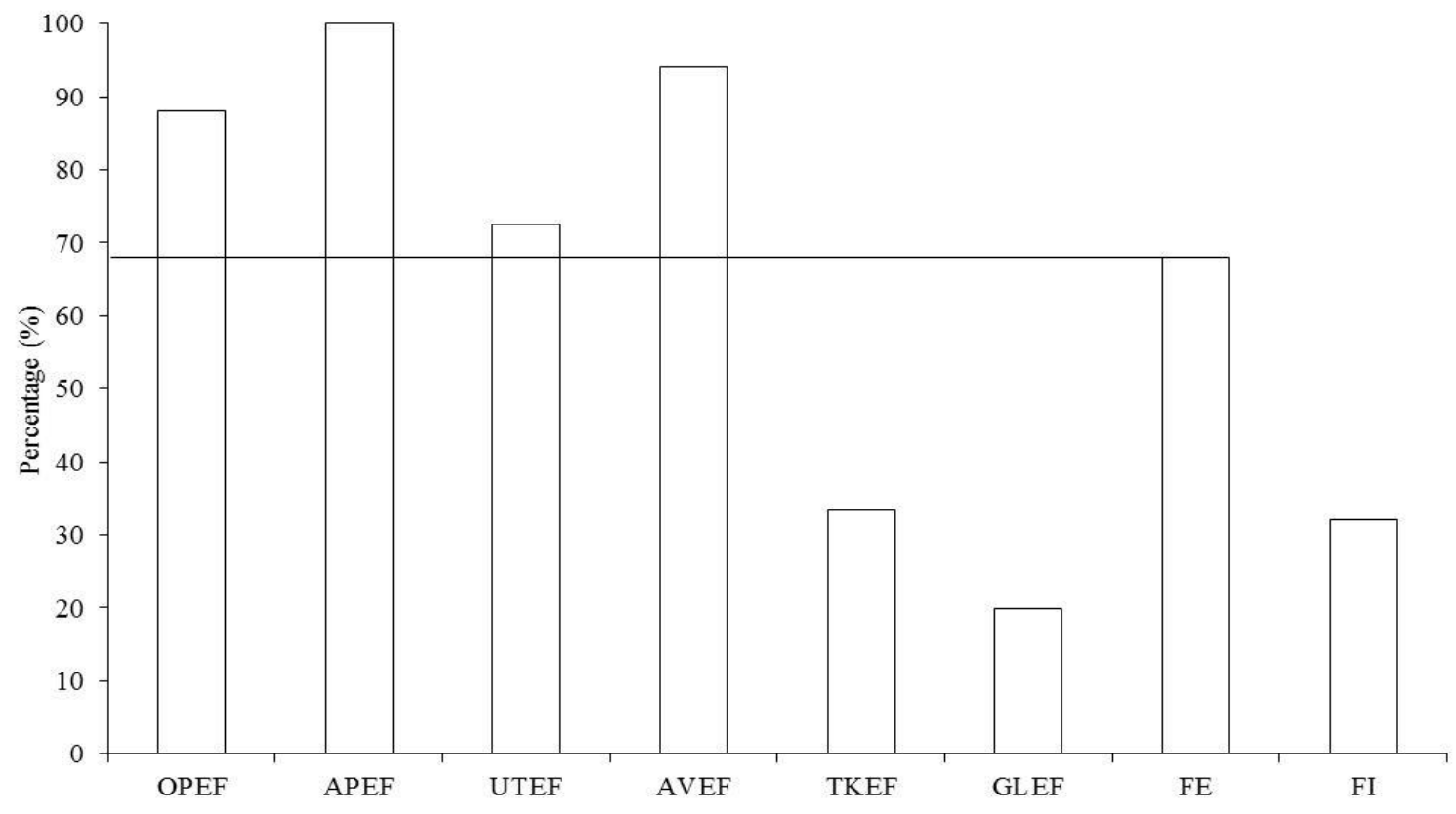

Nucleus,v.15,n.1,abr.2018 
OPEF demonstrates the impact of machine operation auxiliary functions on daily yield, which corresponded to $87.95 \%$. According to the conditions imposed for operation, APEF was $100 \%$ since the harvester presented has a full use of the hours used and suitable. The UTEF was $72.44 \%$ due to the influence from lost hours on harvester daily yield.

As for the influence from maintenance hours on machine daily performance, AVEF was equivalent to $93.97 \%$. TKEF resulted in $33.33 \%$, which is equivalent to $1 / 3$ of the daily working hours $(8 \mathrm{~h})$, as required by the Brazilian labor standards. The GLEF corresponds to the percentage of daytime the harvester is actually processing raw material, which was of $19.96 \%$. According to the conditions imposed to the mechanized harvesting of the plant, the FE was $67.95 \%$. Nevertheless, the FI was $32.05 \%$ due to agricultural management failures.

\section{CONCLUSION}

The decrease in TLO increases machine PRT and TWR.

OPEF and UTEF have strong influence on sugarcane mechanized harvesting operational performance.

Processing plants must adopt excellent management methods to achieve good times and efficiencys indicators.

\section{REFERENCES}

ABDEL MAWLA, H. A.et al. Field evaluation and crop conditions related to sugar cane mechanical harvesting. Egyptian Journal of Agricultural Research, Giza, v. 92, n. 1, p. 257-271, 2014.

BALASTREIRE, L. A. Máquinas agrícolas. São Paulo: Manole, 1990. 307 p.

BANCHI, A. D.; LOPES, J. R. Gestão das operações agrícolas I. Revista Agrimotor, São Paulo, n. 21, p. $12-14,2007$.

BANCHI, A. D.et al. Eficiência global da operação de colheita-cultura da cana-de-açúcar. Revista Agrimotor, São Paulo, n. 16, p. 22-27, 2012.

BANCHI, A. D.; LOPES, J. R.; ZAGO, C. A. Estudo de eficiência das colhedoras de cana-de-açúcar. Revista Agrimotor, São Paulo, n. 32, p. 8-9, 2008.

CONAB - COMPANHIA NACIONAL DE ABASTECIMENTO. Acompanhamento da safra brasileira: cana-de-açúcar, primeiro levantamento. Brasília, v. 4, n. 1, 2017. Disponível em: <http://www.conab.gov.br/OlalaCMS/uploads/arquivos/17_04_20_14_04_31_boletim_cana_portugues__1o_lev_-_17-18.pdf>. Acesso: 17 maio 2017.

CERVI, R. G.et al. Avaliação do desempenho operacional da colheita e transbordo de cana-de-açúcar (Saccharum spp.). Revista Energia na Agricultura, Botucatu, v. 30, n. 3, p. 232-241, 2015. DOI: 10.17224/EnergAgric.2015v30n3p232-241

GONÇALVES, N. G.et al. Eficiências de uso de máquinas agrícolas. In: Congresso Nacional da Sociedade de Técnicos Açucareiros e Alcooleiros do Brasil, 5., Águas de São Pedro. 1993, Anais... Piracicaba: STAB, 1993, p. 165-168. 
HANSEN, A. C.; BARNES, A. J.; LYNE, P. W. L. Simulation modeling of sugarcane harvest-to-mill delivery systems. Transactions of the ASAE, St. Joseph, v. 45, n. 3, p. 531-538, 2002. DOI: $10.13031 / 2013.8819$

HANSEN, A. C.; ZHANG, Q.; WILCOX, T. A. Modeling and analysis of row crop harvesting patterns by combines. Transactions of the ASABE, St. Joseph, v. 50, n. 1, p. 5-12, 2007. DOI: 10.13031/2013.22397

LINHARES, M.et al. Eficiência e desempenho operacional de máquinas harvester e forwarder na colheita florestal. Pesquisa Agropecuária Tropical, Goiânia, v. 42, n. 2, p. 212-219, 2012.

MA, S.et al. Performance evaluation of a chopper harvester in Hawaiian sugarcane fields. Transactions of the ASABE, St. Joseph, v. 58, n. 2, p. 271-279, 2015. DOI: 10.13031/aim.20141898120

MIALHE, L. G. Manual de mecanização agrícola. São Paulo: Agronômica Ceres, 1974. 301 p.

RAMOS, C. R. G. Desempenho operacional da colheita mecanizada de cana-de-açúcar (Saccharum spp.) em função da velocidade de deslocamento e rotação do motor da colhedora. 2013. $72 \mathrm{f}$. Dissertação (Mestrado em Agronomia) - Universidade Estadual Paulista "Júlio de Mesquita Filho", Botucatu.

SANTOS, N. B.et al. Simulação da eficiência de campo da colheita mecanizada de cana-de-açúcar (Saccharum spp.). Revista Energia na Agricultura, Botucatu, v. 29, n. 1, p. 09-13, 2014a. DOI: 10.17224/EnergAgric.2014v29n1p09-13

SANTOS, N. B. dos et al. Tempo é dinheiro. Cultivar Máquinas, Pelotas, n. 149, p. 36-38, 2015.

SANTOS, N. B. dos; SILVA, R. P.; GADANHA JUNIOR, C. D. Economic analysis for sizing of sugarcane (Saccharum spp.) mechanized harvesting. Engenharia Agrícola, Jaboticabal, v. 34, n. 5, p. 945-954, 2014b. DOI: 10.1590/S0100-69162014000500013

SILVEIRA, G. M.; YANAI, K.; KURACHI, S. A. H. Determinação da eficiência de campo de conjuntos de máquinas convencionais de preparo do solo, semeadura e cultivo. Revista Brasileira de Engenharia Agrícola e Ambiental, Campina Grande, v. 10, n. 1, p. 220-224, 2006. DOI: 10.1590/S141543662006000100032

SIMÕES, D.; SILVA, M. R. da; FENNER, P. T. Desempenho operacional e custos da operação de subsolagem em área de implantação de eucalipto. Bioscience Journal, Uberlândia, v. 27, n. 5, p. 692-700, 2011.

VIATOR, R. P.et al. Sugarcane chopper harvester extractor fan and ground speed effects on yield and quality. Applied Engineering in Agriculture, St. Joseph, v. 23, n. 1, p. 31-34, 2007. DOI: $10.13031 / 2013.22327$

YADAV, R. N. S.et al. Performance evaluation of sugarcane chopper harvester. Sugar Tech, New Delhi, v. 4, n. 3-4, p. 117-122, 2002. DOI: 10.1007/BF02942692

YOUSIF, L. A.; DAHAB, M. H.; EL RAMLAWI, H. R. Crop-machinery management system for field operations and farm machinery selection. Journal of Agricultural Biotechnology and Sustainable Development, Victoria Island, v. 5, n. 5, p. 84-90, 2013. DOI: 10.5897/JABSD2013.0205 